\title{
Verbal autopsy of neonatal deaths in Khatauli Block of District Muzaffarnagar,
}

\section{Uttar Pradesh, India}

\author{
Muzammil K1, Singh JV², Shankar R ${ }^{3}$
}

${ }^{1}$ Associate Professor, Department of Community Medicine, Muzaffarnagar Medical College,

Muzaffarnagar, Uttar Pradesh, India

2 Professor \& Head, Department of Community Medicine, Muzaffarnagar Medical College,

Muzaffarnagar, Uttar Pradesh, India

3 First Year Post Graduate Resident, Department of Community Medicine, Muzaffarnagar Medical

College, Muzaffarnagar, Uttar Pradesh, India

Chief Editor

Dr. Jayadeven Sreedharan

Technical Editor

Dr. Nishida Chandrasekharan

Formatting Editor

Dr. Indrajit Banerjee

\section{Original Article}

\section{Corresponding Author}

Dr. Khursheed Muzammil, MD

Associate Professor, Community Medicine

Muzaffarnagar Medical College, Muzaffarnagar,

Uttar Pradesh, India

E-mail: drkmb25@yahoo.com

\section{Abstract}

\section{Background}

Verbal autopsy is a method of inquiry to ascertain the likely cause of death in populations where vital registration of deaths is incomplete and unreliable. Over $75 \%$ of deaths in India occur at homes; more than half of these do not have a certified cause. Further, most of the deaths in the rural areas of India occur at home and that is why a medical certification by a qualified practitioner is not possible.

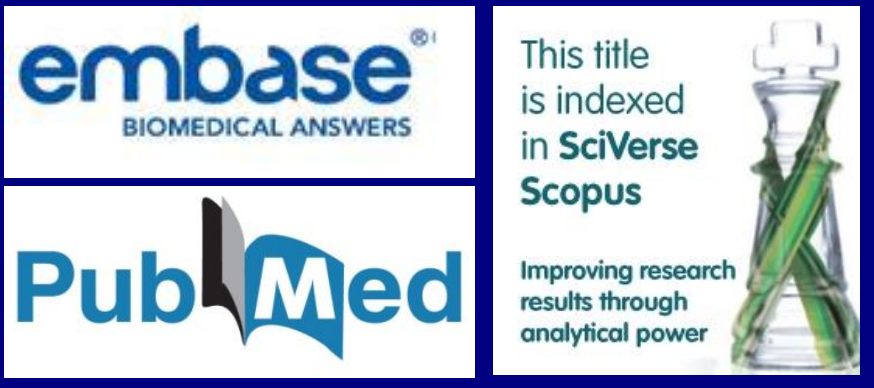

Keeping these facts in mind, this study was designed having objectives as to find out the causes of neonatal deaths through verbal autopsy and its feasibility to be used by health workers.

\section{Material \& Methods:}

This cross-sectional epidemiological study was conducted in randomly selected rural areas of Khatauli Block of District Muzaffarnagar, Uttar Pradesh, India. Verbal autopsy data was collected by a team of health workers adequately trained for the same well in advance. Data related to reported neonatal deaths in the study area in the specified period of time was collected on structured $\&$ pre-tested questionnaire used as study tool by interviewing the parents, relatives or neighbours of the deceased. Data thus collected was verified twice by the coordinator and principal investigator respectively and analyzed by using Epi info statistical package.

Results:

A total of 24 perinatal deaths were reported, out of which 7 (29.2\%) were stillbirth and $17(70.8 \%)$ were neonatal deaths. ANC was received by 14 mothers (58.3\%). Half of the deliveries were conducted by untrained Dai. About 20 
deliveries (83.3\%) were at home and 10 (58.8\%) of the deceased were early neonates. The cause of deaths found by means of verbal autopsies were mainly: pneumonia - 4 (23.5\%), diarrhoea - 2 (11.8\%) neonatal jaundice - 03 $(17.6 \%)$ etc.

\section{Conclusion:}

Pneumonia, diarrhoea \& neonatal jaundice alone constitute about $53 \%$ of the total neonatal deaths. The use of the verbal autopsy tool by health workers to find out the cause of neonatal deaths is very much feasible.

Key words: Verbal autopsy, neonatal deaths, pneumonia, diarrhoea.

\section{Background}

Verbal autopsy is a method of inquiry to ascertain the likely cause of death in populations where vital registration of deaths is incomplete and unreliable. It may be defined as an investigation of the chain of events or circumstances preceding death through interview of the mother or any other person who was looking after the patient, focusing on easily recognizable signs and symptoms ${ }^{1}$. The term "verbal autopsy" was first proposed by Arnold Kielman and coworkers and quoted in a publication in $1983^{2}$.

Over $75 \%$ of deaths in India occur in the home; more than half of these do not have a certified cause. India and other developing countries urgently need reliable quantification of the causes of death ${ }^{3}$. As most of the deaths in the rural areas of India occur at home, medical certification by a qualified practitioner is not possible, thus there is a need for verbal autopsy. Verbal autopsies have been validated and used for ascertaining the cause of death in many countries. In 1992, recognizing the need for uniform and valid criteria for diagnosing common causes of death, Bang AT and Bang RA proposed a set of criteria for the cause of death among neonates and those aged 1-59 months ${ }^{4}$.

Studies employing verbal autopsy have been conducted for research and planning purposes since the 1930s, although its first detailed and thorough application was in 1990 at Johns Hopkins University. The method is based on getting information about deceased persons, whose families allow investigation of the diseases that caused the deaths. In this way, inadequacy of information due to the absence of a health professional before the death can be overcome ${ }^{5}$.

The verbal autopsy method is based on three assumptions, as follows:

1. Various diseases can be distinguished based on their major clinical findings and symptoms. The validity of the method is high when the patient has clear findings, when these findings exist in all other such cases resulting in death, and when findings for other fatal illnesses are not present.

2. Reports by the family of the deceased are vital in the identification of the prominence and severity of the signs and symptoms.

3. The time interval after death is important to the identification and recollection of signs and symptoms ${ }^{5}$.

Information on births and death are important for estimating a society's health needs and necessary health services. Verbal autopsy tool had high sensitivity and specificity in both neonatal and post neonatal deaths. Keeping these facts in mind, this study was designed having objectives as to find out the causes of neonatal deaths through verbal autopsy and its feasibility to be used by health workers.

\section{Material and Methods}

Study design and the participants: It was a cross-sectional epidemiological study considering the deceased neonates as the study subjects.

Data collection/ methodology: This study was conducted in randomly selected 6 rural areas of Khatauli Block of District Muzaffarnagar, which is field practice area of Rural Health Training Center of the Department of Community Medicine, Muzaffarnagar Medical College, Muzaffarnagar, UP, India. First, a house to house survey was conducted to find out the number of perinatal deaths in the study areas, then data pertaining to the specific cause of neonatal deaths during $1^{\text {st }}$ April 2014 to $30^{\text {th }}$ September 2014 (past six months) was collected with the help of verbal autopsy study tool in between $1^{\text {st }}$ October 2014 to $30^{\text {th }}$ November 2014. The study tool was structured and pretested one and has five sections viz., socio-demographic profile of the respondents, environmental profile of the respondents, obstetrical history of the mother of the deceased neonates, delivery profile of the mother of the deceased neonates, profile of the deceased neonate and informations related to the mortality of the neonates. Verbal autopsy data was collected by a team of health workers adequately trained for the same well in advance by interviewing the parents, relatives and neighbours of the deceased and subsequently recorded on the verbal autopsy tool. On moral ground the health workers visited the deceased family only after a period of not less than one month. Prior consent was taken and the purpose of the study was adequately explained before administering the study tool upon the concerned respondents. Data thus collected was verified twice by the coordinator and principal investigator respectively and analyzed by using Epi info statistical package.

Inclusion criteria: All such respondents who wish to be part of this study were included.

Exclusion criteria: Neonatal deaths beyond the study period were excluded.

Sample size calculation: The respondents of all the reported neonatal deaths during $1^{\text {st }}$ April 2014 to $30^{\text {th }}$ November 2014 who gave their consent to be part of this study constituted the sample size.

Outcome Variable: Cause of neonatal deaths.

Explanatory variable: Illiteracy, socioeconomic status. 
Ethical committee approval: IEC approval was taken before the start of the study.

Data management and statistical analysis:

Epi info statistical software was used for data recording and drawing up of suitable inferences.

Result:

A total of 708 births took place in the study area, 29 infant deaths and 24 perinatal deaths were reported in the same study area during the six months study period extending from $1^{\text {st }}$ April to $30^{\text {th }}$ September 2015. Among the 24 perinatal deaths, 7 (29.2\%) were still birth and 17 (70.8\%) were neonatal deaths. All (100\%) the neonatal deaths were subjected to study tool and our study revealed the following findings about the cause of neonatal deaths with the help of verbal autopsy. Table-1 shows that maximum families were nuclear (70.8\%). All the respondents were Hindu by religion. $45.5 \%$ of the mothers of the deceased were illiterate. $25 \%$ of fathers were labourer. Majority (37.5\%) of the parents belonged to class IV socio-economic status. Overcrowding was present in about $83.3 \%$ of the families.

Table-1: Socio-demographic \& environmental profile of deceased.

\begin{tabular}{|c|c|c|c|c|}
\hline $\begin{array}{l}\text { Sl. } \\
\text { No }\end{array}$ & Traits & & $\begin{array}{c}\text { No. } \\
(n=24)\end{array}$ & Percentage \\
\hline 1. & $\begin{array}{l}\text { Type of } \\
\text { family }\end{array}$ & $\begin{array}{l}\text { Nuclear } \\
\text { Joint }\end{array}$ & $\begin{array}{c}17 \\
7\end{array}$ & $\begin{array}{l}70.8 \\
29.2\end{array}$ \\
\hline 2. & Religion & $\begin{array}{l}\text { Hindu } \\
\text { Others }\end{array}$ & $\begin{array}{c}18 \\
6\end{array}$ & $\begin{array}{l}75.0 \\
25.0\end{array}$ \\
\hline 3. & Occupation: & $\begin{array}{l}\text { Father: } \\
\text { Labourer/ Farmer } \\
\text { Other } \\
\text { Mother: } \\
\text { Labourer/ Farmer } \\
\text { Others (Housewife) }\end{array}$ & $\begin{array}{c}13 \\
11 \\
\\
3 \\
21\end{array}$ & $\begin{array}{l}54.2 \\
45.8 \\
\\
12.5 \\
87.5\end{array}$ \\
\hline 4. & $\begin{array}{l}\text { Socio } \\
\text { economic } \\
\text { status } \\
\text { (Modified } \\
\text { Prasad's } \\
\text { Classification) }\end{array}$ & $\begin{array}{l}\text { Upper (class - I) } \\
\text { Upper middle (class-II) } \\
\text { Lower middle (class-IV) } \\
\text { Upper lower (class-IV) } \\
\text { Lower (class-IV) }\end{array}$ & $\begin{array}{l}2 \\
4 \\
2 \\
9 \\
7\end{array}$ & $\begin{array}{l}08.3 \\
16.7 \\
08.3 \\
37.5 \\
29.2\end{array}$ \\
\hline 5. & $\begin{array}{l}\text { Housing } \\
\text { Condition }\end{array}$ & $\begin{array}{l}\text { Kachcha } \\
\text { Semi pukka/ Pukka }\end{array}$ & $\begin{array}{l}11 \\
13\end{array}$ & $\begin{array}{l}45.8 \\
54.2\end{array}$ \\
\hline 6. & Overcrowding & $\begin{array}{l}\text { Present } \\
\text { Absent }\end{array}$ & $\begin{array}{c}20 \\
4\end{array}$ & $\begin{array}{l}83.3 \\
16.7\end{array}$ \\
\hline 7. & Ventilation & $\begin{array}{l}\text { Adequate } \\
\text { Inadequate }\end{array}$ & $\begin{array}{c}4 \\
20\end{array}$ & $\begin{array}{l}16.7 \\
83.3\end{array}$ \\
\hline 8. & $\begin{array}{l}\text { Mode of } \\
\text { water supply }\end{array}$ & $\begin{array}{l}\text { Tap water } \\
\text { Hand pump }\end{array}$ & $\begin{array}{c}9 \\
15\end{array}$ & $\begin{array}{l}37.5 \\
62.5\end{array}$ \\
\hline 9. & $\begin{array}{l}\text { Drainage } \\
\text { system }\end{array}$ & $\begin{array}{l}\text { Present (Open type) } \\
\text { Absent }\end{array}$ & $\begin{array}{l}24 \\
-\end{array}$ & $\begin{array}{c}100 \\
-\end{array}$ \\
\hline
\end{tabular}

Table-2 depicts that only $58.3 \%$ of the mothers had antenatal check-ups. $16.7 \%$ of the deliveries took place before 37 weeks. About $41.7 \%$ of the deliveries were complicated and among them the main complication was excessive bleeding (80\%).

Table- 2: Obstetrical history of the mother of the deceased

\begin{tabular}{|l|c|c|c|}
\hline SI. No & Traits & $\begin{array}{c}\text { Number } \\
(\mathrm{n}=24)\end{array}$ & Percentage \\
\hline $\mathbf{1 .}$ & ANC received & & \\
& Yes & 14 & 58.3 \\
No & 10 & 41.7 \\
\hline $\mathbf{2 .}$ & T.T vaccination receive & & \\
& Yes & 16 & 66.7 \\
& No & 8 & 33.3 \\
\hline $\mathbf{3 .}$ & Delivery ended & & \\
& Early & 4 & 16.7 \\
& At time & 18 & 75.0 \\
& Late & - & - \\
Don't know & 2 & 08.3 \\
\hline $\mathbf{4 .}$ & Delivery status & & \\
& Normal & 14 & 58.3 \\
& Complicated & 10 & 41.7 \\
\hline
\end{tabular}

Table- 3 shows that about $29.2 \%$ of the births were still birth. $50 \%$ of the deliveries were conducted by untrained Dais. Majority (83.3\%) of deliveries took place at home \& unsterile blade was used in $25 \%$ of the cases to cut the cord.

Table- 3: Delivery profile of the mother of the deceased.

\begin{tabular}{|c|c|c|c|}
\hline $\begin{array}{l}\text { SI. } \\
\text { No }\end{array}$ & Traits & Number & Percentage \\
\hline 1. & $\begin{array}{l}\text { Pregnancy outcome }(n=24) \\
\text { Live birth } \\
\text { Still Birth }\end{array}$ & $\begin{array}{c}17 \\
7\end{array}$ & $\begin{array}{l}70.8 \\
29.2\end{array}$ \\
\hline 2. & $\begin{array}{l}\text { Time that delivery took }(n=24) \\
\qquad \begin{array}{l}<12 \\
>12\end{array}\end{array}$ & $\begin{array}{c}16 \\
8\end{array}$ & $\begin{array}{l}66.7 \\
33.3\end{array}$ \\
\hline 3. & $\begin{array}{l}\text { Delivery conducted by:- }(n=24) \\
\text { Qualified doctor } \\
\text { Nurse } \\
\text { Trained dai } \\
\text { Untrained dai } \\
\text { Relatives/others }\end{array}$ & $\begin{array}{c}2 \\
3 \\
6 \\
12 \\
1\end{array}$ & $\begin{array}{c}8.3 \\
12.5 \\
25.0 \\
50.0 \\
4.2\end{array}$ \\
\hline 4. & $\begin{array}{l}\text { Place of delivery }(\mathrm{n}=24) \\
\text { Home } \\
\text { Institutional }\end{array}$ & $\begin{array}{c}20 \\
4\end{array}$ & $\begin{array}{l}83.3 \\
16.7\end{array}$ \\
\hline 5. & $\begin{array}{l}\text { Instrument used to cut the } \\
\text { cord }(n=24) \\
\text { Blade } \\
\text { Others }\end{array}$ & $\begin{array}{c}24 \\
-\end{array}$ & $\begin{array}{c}100.0 \\
-\end{array}$ \\
\hline 6. & $\begin{array}{l}\text { Sterilization of the instrument } \\
(n=24) \\
\text { Done } \\
\text { Not done }\end{array}$ & $\begin{array}{c}18 \\
6\end{array}$ & $\begin{array}{l}75.0 \\
25.0\end{array}$ \\
\hline 7. & $\begin{array}{c}\text { Baby cried at birth }(n=24) \\
\text { Yes } \\
\text { No }\end{array}$ & $\begin{array}{c}17 \\
7\end{array}$ & $\begin{array}{l}70.8 \\
29.2\end{array}$ \\
\hline 8. & $\begin{array}{l}\text { Application on the cord }(n=17) \\
\text { Antiseptic/ Haldi } \\
\text { Ash } \\
\text { Nothing applied }\end{array}$ & $\begin{array}{c}2 \\
1 \\
14\end{array}$ & $\begin{array}{c}11.8 \\
5.9 \\
82.3\end{array}$ \\
\hline 9. & $\begin{array}{c}\text { Dressing - cord \& stump }(\mathrm{n}=17) \\
\text { Clean with cotton } \\
\text { No dressing }\end{array}$ & $\begin{array}{c}4 \\
13\end{array}$ & $\begin{array}{l}23.5 \\
76.5\end{array}$ \\
\hline
\end{tabular}


Table- 4: Profile of the deceased

\begin{tabular}{|c|c|c|c|}
\hline SI. No & Traits & Number & Percentage \\
\hline 1. & $\begin{array}{l}\text { Presence of bruise/mark of } \\
\text { injury at birth }(n=24) \\
\text { Yes } \\
\text { No }\end{array}$ & $\begin{array}{c}6 \\
18\end{array}$ & $\begin{array}{l}25.0 \\
75.0\end{array}$ \\
\hline 2. & $\begin{array}{l}\text { Size of the baby at the time of } \\
\text { birth }(n=24) \\
\text { Normal Size } \\
\text { Longer than usual } \\
\text { About average } \\
\text { Smaller than usual } \\
\text { Very small }\end{array}$ & $\begin{array}{c}1 \\
3 \\
13 \\
3 \\
4\end{array}$ & $\begin{array}{l}04.2 \\
12.5 \\
54.2 \\
12.5 \\
16.6\end{array}$ \\
\hline 3. & $\begin{array}{l}\text { Color of the baby at the time of } \\
\text { birth }(n=24) \\
\text { Pale } \\
\text { Blue } \\
\text { Pink }\end{array}$ & $\begin{array}{c}5 \\
4 \\
15\end{array}$ & $\begin{array}{l}20.8 \\
16.7 \\
62.5\end{array}$ \\
\hline 4. & $\begin{array}{l}\text { Birth weight of the baby }(n=24) \\
\text { Taken } \\
\text { Not taken } \\
\text { If taken then }(n=4) \\
\quad<2.5 \mathrm{~kg} \\
\geq 2.5 \mathrm{~kg}\end{array}$ & $\begin{array}{c}4 \\
20 \\
3 \\
1\end{array}$ & $\begin{array}{l}16.7 \\
83.3 \\
75.0 \\
25.0\end{array}$ \\
\hline 4. & $\begin{array}{l}\text { Type of feeding ( } \mathrm{n}=17) \\
\text { Exclusive breast feeding } \\
\text { Partial breast feeding } \\
\text { Total top feeding }\end{array}$ & $\begin{array}{l}9 \\
2 \\
6\end{array}$ & $\begin{array}{l}52.9 \\
11.8 \\
35.3\end{array}$ \\
\hline 5. & $\begin{array}{l}\text { Colostrum given }(n=17) \\
\text { Yes } \\
\text { No }\end{array}$ & $\begin{array}{c}12 \\
5\end{array}$ & $\begin{array}{l}70.6 \\
29.4\end{array}$ \\
\hline
\end{tabular}

Table- 5: Informations related to the deceased.

\begin{tabular}{|c|c|c|c|}
\hline Sl. No & Traits & Number & Percentage \\
\hline 1. & $\begin{array}{l}\text { Sex of the deceased }(n=24) \\
\text { Male } \\
\text { Female }\end{array}$ & $\begin{array}{l}10 \\
14\end{array}$ & $\begin{array}{l}41.7 \\
58.3\end{array}$ \\
\hline 2. & $\begin{array}{l}\text { Place of death }(n=24) \\
\text { Home } \\
\text { Institutional }\end{array}$ & $\begin{array}{c}19 \\
5\end{array}$ & $\begin{array}{l}79.2 \\
20.8\end{array}$ \\
\hline 3. & $\begin{array}{l}\text { Relationship of the informant } \\
\text { to the deceased }(n=24) \\
\text { Father } \\
\text { Mother } \\
\text { Relative }\end{array}$ & $\begin{array}{c}5 \\
12 \\
7\end{array}$ & $\begin{array}{l}20.8 \\
50.0 \\
29.2\end{array}$ \\
\hline 4. & $\begin{array}{l}\text { Age of the deceased (live birth) } \\
\begin{array}{l}(\mathrm{n}=17) \\
\quad \leq 7 \text { days } \\
>7 \text { to } 28 \text { days }\end{array}\end{array}$ & $\begin{array}{l}10 \\
07\end{array}$ & $\begin{array}{l}58.8 \\
41.2\end{array}$ \\
\hline 5. & $\begin{array}{l}\text { Duration of illness before } \\
\text { death }(n=17) \\
\qquad \begin{array}{l}\leq \text { day } \\
>1 \text { day }\end{array}\end{array}$ & $\begin{array}{l}8 \\
9\end{array}$ & $\begin{array}{l}47.0 \\
53.0\end{array}$ \\
\hline 6. & $\begin{array}{l}\text { Health records \& death } \\
\text { certificates }(n=17) \\
\text { Present } \\
\text { Absent }\end{array}$ & $\begin{array}{c}3 \\
14\end{array}$ & $\begin{array}{l}17.6 \\
82.3\end{array}$ \\
\hline 7. & $\begin{array}{l}\text { Immediate cause of death as } \\
\text { per verbal autopsy tool }(n=17) \\
\text { Birth asphyxia } \\
\text { Birth injury } \\
\text { Congenital } \\
\text { abnormalities } \\
\text { Diarrhoea } \\
\text { Pneumonia } \\
\text { Malnutrition } \\
\text { Unknown fever (PUO) } \\
\text { Fall from height } \\
\text { Neonatal jaundice } \\
\text { Twin pregnancy } \\
\text { Others }\end{array}$ & $\begin{array}{l}1 \\
1 \\
1 \\
2 \\
4 \\
1 \\
1 \\
1 \\
1 \\
3 \\
1 \\
1\end{array}$ & $\begin{array}{c}5.9 \\
5.9 \\
5.9 \\
11.8 \\
23.5 \\
5.9 \\
5.9 \\
5.9 \\
17.6 \\
5.9 \\
5.9\end{array}$ \\
\hline
\end{tabular}

Table-4 depicts that only one newborn was normal in size. Birth weight was taken in only $16.7 \%$ of the cases and among them $75 \%$ were low birth weight babies. About $20.8 \%$ of the newborns were pale at the time of birth. $35.5 \%$ of the newborns were on complete top feeding. Colostrum was not given in $29.4 \%$ of the cases. Breast feeding was started immediately after birth in only $11.8 \%$ of the newborns.

Table-5 depicts that $58.8 \%$ of the deceased were early neonates. Maximum deceased (58.3\%) were females. Maximum deaths (79.2\%) took place at home. Majority of the informants $(50 \%)$ were mothers of the deceased. The cause of deaths found by means of verbal autopsies were mainly- pneumonia (23.5\%), diarrhoea (11.8\%) neonatal jaundice (17.6\%), whereas birth asphyxia, birth injuries, congenital anomalies, malnutrition, pyrexia of unknown origin, fall from height, twin pregnancy and others contributed $5.9 \%$ each.

\section{Discussion \\ Verbal autopsy tool}

The verbal autopsy has been administered by research workers or experts to find out the feasibility and practicality of its use in various studies. In addition, in such studies, all deaths taking place in the study sample are likely to be covered; unlike in a routine system, where all deaths may not be registered and investigated. However, if one has to use the verbal autopsy as an instrument for ascertaining causes of death on a nationwide scale, it should be possible for health care providers at all levels to be able to use this tool, and should be incorporated along with the routine health systems ${ }^{1}$.

\section{Sensitivity \& Specificity of the tool}

In 1993, a verbal autopsy tool was developed for use in Comprehensive Rural Health Services Project Ballabgarh ${ }^{6}$. This tool had high sensitivity and specificity in both neonatal and post neonatal deaths ${ }^{7}$. Since 1999 , it was decided that the health workers themselves should use the verbal autopsy for all under five deaths in their field practice area. This is being carried out as a part of routine activity and covers all the under-five deaths in the villages under the project area ${ }^{1}$.

\section{Main causes of neonatal deaths}

Similar effort has also been tried in the present study to aid the local level health managers to set up the priority areas as per the findings of the verbal autopsy. In the present study it was found that the main causes of neonatal deaths were pneumonia (23.5\%), neonatal jaundice (17.6\%), diarrhoea (11.8\%), birth asphyxia (5.9\%), birth injuries (5.9\%), congenital anomalies (5.9\%), twin pregnancy (5.9\%), etc., whereas a similar study reported birth asphyxia (18\%), prematurity (16\%), low birth weight/ small for date (14\%), septicemia (10\%), Congenital anomalies (8\%) and others 
(34\%) as the causes of neonatal deaths as per verbal autopsy. ${ }^{(1)}$ In our study, we found that prematurity was not an important precipitating factor for the cause of neonatal deaths as is the case in similar other Indian studies ${ }^{8,9}$. However, we found that pneumonia was the leading cause of death, which points to the quality of nursing and health care. Different results were observed in different studies and this may be due to the different areas, varied population and also varied environmental conditions.

\section{Uses of Verbal Autopsy}

We have seen that the verbal autopsy can be used for two purposes. Firstly, it can, help to give information for the health planners to look into the most common causes of the mortality and prioritize health services based on the mortality pattern of that area. In other words, verbal autopsy can be used for collecting information for action at all the levels. In fact this exercise was a part of an overall strategy to reduce IMR in the field practice area.

\section{Conclusion}

The important cause of neonatal deaths found by means of verbal autopsies were primarily - pneumonia, diarrhoea \& neonatal jaundice; accounting together for about $53 \%$ of the total neonatal deaths. Verbal autopsy is the most feasible tool to be used by the health workers which is not only user friendly but also an easy method to ascertain the likely cause of neonatal deaths indeed.

\section{Limitation of the study:}

Only neonatal deaths were included.

Future scope of the study:

Such studies at a wider scale can be conducted in other regions also if adequate funds are allocated for the same.

\section{Author's Contribution:}

$\mathrm{KM}$ is responsible for designing, conduction of the study as principal investigator \& manuscript write up, JVS is responsible for overall monitoring of the execution \& coordination of the study \& approval of the final manuscript and RS for data entry in Epi info statistical software and drawing up of inferences.

\section{Acknowledgements:}

The authors are thankful to all the field workers and respondents for extending their support in the execution of the study.

\section{Conflict of interest:}

There is no conflict of interest among authors arising from the study.

\section{References:}

Verbal autopsy of neonatal deaths

1. Nongkynrih B, Anand K, Kapoor SK. Use of Verbal Autopsy by Health Workers in Under-Five Children. Indian Pediatr 2003; 40: 766-771. PMid:12951380

2. Kielman A, Desweemer C, Parker R, Taylor C. Analysis of morbidity and mortality. In: Child and maternal health services in rural India, the Narangwal experiment Vol.1: Integrated nutrition and health care. Baltimore (MD): Johns Hopkins University Press; 1983: 172-214.

3. Jha P, Gajalekshmi V, Gupta PC, Kumar R, Mony P, Dhingra $\mathrm{N}$ et al. Prospective Study of One Million Deaths in India: Rationale, Design, and Validation Results. RGI-CGHR Prospective Study Collaborators. PLoS Med. 2006; 3(2): e18. Published online Dec 20, 2005: p. 0191-0200 (doi: 10.1371/journal.pmed.0030018) [PMCID: PMC1316066]

4. Bang AT, Bang RA. Diagnosis of causes of childhood deaths in developing countries by verbal autopsy: suggested criteria. Bull WHO 1992; 70: 499-507. PMid:1394784 PMCid:PMC2393390

5. Verbal Autopsy Survey Interim Report. National burden of disease and cost effectiveness project. Min. of Health, Refik Saydam Hygiene Center Presidency School of Public Health, Baskent University, Ankara; 24th Dec 2003: 10.

6. Anand K, Kant S, Kumar G, Kapoor SK. Development is not essential to reduce infant mortality rate in India: experience from the Ballabgarh project. J Epidemiol Community Health 2000; 54: 247-253. http://dx.doi.org/10.1136/jech.54.4.247

PMid:10827906 PMCid:PMC1731664

7. Longjam UD. A study of causes of death in children under five years using verbal autopsy as a diagnostic tool. Thesis submitted for M.D. in Community Medicine, All India Institute of Medical Sciences, New Delhi; 1995.

8. Awasthi S, Pande VK. Cause specific mortality in under fives in the urban slums of Lucknow, North India. J Trop Pediatr 1998; 44: 358-362. http://dx.doi.org/10.1093/tropej/44.6.358

9. Srivastava SP, Kumar A, Ojha AK. Verbal autopsy determined causes of neonatal deaths. Indian Pediatr 2001; 38: 1022-1024.

\begin{tabular}{|l|c|}
\hline \multicolumn{2}{|c|}{ Article Information } \\
\hline \multicolumn{2}{|c|}{ Article history } \\
\hline Received & $4^{\text {th }}$ December 2014 \\
\hline Received in revised form & $20^{\text {th }}$ December 2014 \\
\hline Accepted & $29^{\text {th }}$ December 2014 \\
\hline
\end{tabular}

